\title{
Cultural Pluralism on the Example of National Minorities in the United States of America
}

\author{
Kamila Ziólkowska-Weiss \\ Ph.D., Pedagogical University of Cracow (Kraków, Poland) \\ E-mail: kamila.ziolkowska-weiss@up.krakow.pl \\ https://orcid.org/0000-0001-6575-5314
}

Ziółkowska-Weiss, Kamila (2020) Cultural pluralism on the example of national minorities in the United States of America. Ukrainian Policymaker, Volume 6, 114-121. https://doi. org/10.29202/up/6/11

In today's world, issues of cultural pluralism form an essential part of political discussion. Directions are set for the implementation of individual activities, aimed at correcting and coordinating activities in the field of multiculturalism. There is no doubt today that the United States of America has faced a migration challenge that they had to implement in the conditions of American reality. Therefore, this article addresses the issue of cultural pluralism, taking into account every aspect of this complex concept. The author considers this issue from the perspective of historical, sociological, and cultural studies. The interdisciplinary approach is necessary because of the multi-faceted nature of the issue. This case could be heuristic for Ukrainian researchers because the Ukrainian state, aspiring to the integration with Western democratic structures, the question of cultural pluralism is crucial.

Keywords: cultural pluralism, democratic state, migration processes, multiculturalism, social stratification, American migration policy.

Received: May 9, 2020; accepted: May 28, 2020.

\section{Introduction. What is cultural pluralism?}

Nowadays, the term "pluralism" can be encountered more and more often. It appears in scientific and journalistic literature, in discussions between people with different worldviews, in the aspirations of people of "good will" to cooperate in various areas of life and activity (Piwowarski, 1980: 23-28). Cultural pluralism is primarily due to the mixing of races, and thus to the dual ethnic-national identity.

It seems important that sociologists search for and explain specific social and cultural phenomena that occur with particular intensity in highly developed societies. They also represent one of the leading tendencies of these societies. These phenomena are characterized not only by simple multiplicity or diversity, e.g. of ethnic groups, cultures, religions, ideologies but

(C) Ziółkowska-Weiss, Kamila, 2020 
also by a specific situation that can be described as a situation of competition and competition between autonomous entities of social life in terms of basic goals, values and aspirations for a specific common functioning area. This means that developed societies are not "obliged" to adhere to a uniform system of values, beliefs, symbols, and behavioral patterns. Their high awareness of their sense of national identity means that in highly developed countries, the distinctness of individual units in the country is so clearly marked. Hence, pluralism can be talked about wherever there is no monopoly and hegemony of some systems over others. This approach is an important aspect of the implementation of the social policy of each country. In this context, Ukraine is no exception, because for the Ukrainian state, aspiring to the integration with Western democratic structures, the issue of cultural pluralism is significant, especially the analysis of this phenomenon from the perspective of the United States, which is considered a model of democracy in the western world.

One of the types of pluralism is cultural pluralism, which in social life is understood as the functioning of the state or other organization when various groups have the right to express their interests, in particular, to participate in exercising power. Pluralism implies respect for social and cultural diversity and recognition of equal views. Cultural pluralism concerns the conscious effort of minority groups to maintain their ethnicity. A minority simultaneously works to gain political and economic influence in a dominant society. It is a category of the permanent existence of several cultural categories in society, combined with acceptance by the majority group and equality of minority groups. Cultural contact is the result of the communication and meeting of at least two people or groups with different cultural characteristics (Paleczny, 2002: 87-89; 142-146).

Another example of pluralism that democratic countries encounter daily is political pluralism, which assumes that this is one of the principles of the functioning of parliamentary party systems, consisting in the existence of two or more political parties representing different programs and orientations, struggling to gain power in the state (Chmaj, 1999: 49-51). It means the freedom of functioning of many organizations in the country, which is essential in the case of many cultural organizations of minority groups in a given state.

The principle of political pluralism is derived from the idea of individual freedom and equality of all citizens in a sovereign and diverse democratic society. In the system of pluralistic democracy, society is perceived as a whole composed of individuals and social groups that pursue their interests. Society is strongly diversified in political and economic terms - it is therefore pluralistically built. Units to achieve common goals organize themselves to form political, ideological, and cultural organizations of a voluntary nature. The principle of political pluralism applies only to parties legally operating, accepting the basic principles of the constitution, as contained in the constitution of that state (Chmaj \& Marszałek-Kawa, 2004: 87-91; 201-203).

\section{The attitude of the United States towards national minorities and migration movements}

The experiences of multicultural, multi-faith, and diverse in terms of racial, ethnic structure of post-immigration societies have led to the creation of a new model of integration that could not take shape if it were not for the phenomenon of emigration (Paleczny, 2002: 34-37). Therefore, speaking about cultural pluralism in the United States, migration issues, and the US attitude towards host national minorities are essential issues. 
American society is a conglomerate of people of various ethnic and racial backgrounds, with different denominations, cultures, with different economic status, etc. (Kymlicka, 1999: 42-44). The United States currently has the largest immigrant community (i.e., foreign-born people) in the world, with almost 47 million (14.5\% of the US population). This fact means that $1 / 5$ of all immigrants in the world live in America. The number of immigrants in the USA has increased more than four times in the last half-century. Demographers predict a further increase in the share of the foreign-stock category (second generation, i.e., those whose at least one parent was born outside the United States) and foreign-born (people living in the United States but born abroad) in the US population to $18 \%$ of the total population in 2065 . Over the next 50 years, immigration will be a significant factor in the demographic development of the state. Pew Research Center experts predict that the population of the US in 2065 will increase by 117 million and reach 441 million, with $88 \%$ of this increase being immigrants and their children.

In demographic research concerning the United States, special attention was paid to migration because it is a migration that is largely based on the development of American society. From a historical point of view, it consists almost exclusively of immigrants and their descendants. Therefore, the phenomenon of migration to the USA and the attitude of the American government towards the host is important from the economic, economic or cultural development of this country while maintaining the cultural separateness of individual ethnic groups. Thus the United States is a good example where cultural pluralism is visible and respecting the individuality of individual citizens from all over the world. Numerous waves of immigrants to the United States caused that the US over the centuries has been "forced" to introduce certain limits on the admission of immigrants and to introduce a law regulating the arrival of newcomers from other parts of the world. However, no legal regulation introduced by the US government assumed the renunciation of its roots.

The immense size that immigration has taken in the United States in the last decades of the nineteenth century has caused concern over its social and economic consequences for the country. It has introduced the first restrictions on migrants. Despite the huge influx of people, the new laws were not aimed at reducing the size of immigration, but rather for a long time directed against the very nature of the phenomenon. Prostitutes and persons previously convicted of criminal offenses were subject to the first entry ban. Under pressure from trade union pressure, Congress then passed a prohibition on contracting workers to work in the United States, despite the existence of an earlier legal act encouraging such activities.

Immigration and nationality resolutions of 1965 abolished the existing system of limits grouping potential immigrants by their country of origin. In return, a ceiling of 170,000 was set for the entire eastern hemisphere immigrants per year, with the limit for a single state of 20,000. Migration visas were issued on a first-come-first-served basis, in accordance with the seven-point system of preferences, which gives priority to close relatives of US citizens or foreigners permanently resident in the US, persons with sought after skills and professional qualifications and refugees. For the first time, a limit of 120,000 was set immigrants per year in relation to the countries of the Western Hemisphere (however, until 1976, no system of preferences or restrictions for individual countries was introduced). Finally, in 1978, all differences in the treatment of both hemispheres were eliminated, combining both immigration ceilings and setting a typical limit of 290,000 immigrants a year for the whole world. This law also applies today. The ceiling in question, of course, only applies to immigrants, not tourists. However, none of the ceilings that have been in force since 1965 is an adequate measure of 
the size of immigration to the US. The wave of immigration is far higher than it would appear from the set limits, because today, as in the post-war period, immigrant ranks are increasing the number of refugees in the US - regardless of the applicable ceilings.

The constant influx of new immigrants in the 1970s and the inevitable social and economic consequences of this influx triggered a discussion in the US on the goals of immigration law and the country's immigration policy. That is why Congress set up a Special Committee on Immigration and Refugee Policy, which conducted thorough research on immigration issues. These studies focused on the following questions: How many? Whence? According to what criteria? How? (Bastiani, 1984: 23-32). In December 1979, the Commission presented its recommendations to the President and Congress in the field of immigration policy, and the results of the Commission's research were published in a detailed report issued in March 1980. The composition of the Commission, which represented a wide range of different ethnic groups in the US, guaranteed that the results of her work would preserve the American traditions of humanitarianism (law) and asylum while maintaining the separateness of individual national minorities. As one member of the board of the Commission said, that in the future, immigration will never be based on rules that take into account racial or national origin, so, everyone has the right to preserve the roots of his ancestors.

As a result of lifting immigration restrictions in 1965, the influx of migrants increased from 300-400 thousand per year to over 1.4 million per year at the turn of the millennium. In recent decades, the inflow has fallen to $700-900$ thousand per year, which is associated with a reduction in labor demand in the construction and processing industries, as well as a tightening of immigration policy (Mather, 2012: 81-83). The new influx, which continues to this day, consists of Latinos (mainly Mexicans, Salvadorans, Cubans, Dominicans, and Guatemalans) and Asians (Chinese, Hindus, Filipinos, Vietnamese, and Koreans). Since 2009, the influx of migrants from Asia has exceeded the number of Latinos coming to the US.

By around the middle of this century, white Americans will already make up less than half of the country's total population but will remain the largest group. American authors describe this state by the expression majority minority status. According to Mark Mather of the Population Reference Bureau in Washington, this will happen as early as 2042 (Mather, 2012: 4-6).

The waves of migration that have taken place in the United States over the decades have significantly shaped today's multicultural America, in which the concept of cultural pluralism has a special connotation. Post-modern pluralistic societies pursue a multicultural policy based on programs and ideologies for integration, acculturation, and personality assimilation, also supporting the efforts of local communities to maintain their linguistic, religious, ethnic or racial separateness (Paleczny, 2007: 12-14).

\section{The United States of America as an example of cultural pluralism and multiculturalism}

In the literature on the subject, there is often an understanding of cultural pluralism as multiplicity, diversity, and multiculturalism. Specific and exceptional features that distinguish complex, heterogeneous multicultural societies from homogeneous, homogeneous nationstates include a variety of processes of mutual adaptation, acculturation, and assimilation originating from various racial, ethnic, and religious groups of people (Paleczny, 2007: 19-22). 
The United States is a country with an immigrant pedigree that, due to the standard of living it offers, attracts crowds of visitors from all over the world. Multiculturalism, defined by Fish (1997), manifests itself above all in the ethnic diversity of the inhabitants of modern cities. From a sociological point of view, a significant effect of their growth was the development of ethnic groups cultivating various elements of their own cultures. Hence, many urban centers have been and are to some extent, culturally diverse, and therefore multicultural. This phenomenon is conditioned by both the genesis and the development of each of them. It can be read both from their history and from the sociological portrait of the inhabitants. Therefore, the cultural map of the USA is the result of the historical process of its creation, on the one hand, and the migration movements that direct crowds of people to the borders of the world's largest cities, as described above.

We read multiculturalism through the prism of cultural and social features of the inhabitants of a given region. Its foundation is - as highlighted in the text - the phenomenon of migration that directs crowds of people with diverse cultural, ethnic, and social baggage into urbanizing spaces. They bring with them different cultural patterns that display clothing, headgear, language, views, religion, behavior, style, and standard of living. Focused on one space, they form a colorful mosaic. Multicultural countries played an important role in the development of their residents' cultures because they had a structure that took into account their specificity.

Looking at multiculturalism using the cultural studies approaches, it can be said that it is the participation of various minorities in a large social group that dominates in a given area (Gęsiak, 2007: 147-151). There are many concepts of multiculturalism. One of them presents multiculturalism as "a set of neighboring cultures that began to penetrate each other. The coexistence of representatives of two or more cultures in one social group is also multiculturalism" (Olczak, 2002: 61-63). Thus, it can be concluded that the phenomenon presented is based on the various people being next to each other and the contribution of some of them to the general culture of the region, their characteristic features that allow them to preserve their identity and cultural separateness (Gęsiak, 2007: 150-152). According to Marian Golka, multiculturalism is the meeting of different cultural groups with different characteristics such as, for example, external appearance, religion, value system, or language (Golka, 2010: 31-34).

Referring to the definitions of multiculturalism and cultural pluralism, it can be seen that these are different types of relations between a large cultural group occurring in a given region, a kind of social unity, and a cultural minority, which is distinguished by specific features that differ from the local culture. Therefore, cultural pluralism is based on the principles of equality and consists of accepting cultural differences of minorities. In a multicultural society, it is important for a community to be created that has the same rights and obligations, but at the same time allows representatives of different cultures to maintain their identity in this society (Gęsiak, 2007: 162).

Based on the above-mentioned concepts, it can be stated that multiculturalism is mainly related to the movement of people, and in particular, to spatial mobility. The oldest manifestations of this mobility are undoubtedly migrations of people, various migrations, and colonization processes (Golka, 2010: 23-28). Multiculturalism, however, causes different behaviors in societies that come into contact with cultural diversity. Often it is a curiosity that causes the minority to be received with respect and openness to their cultural identity. People interested in the outfit or the language of the arriving are looking forward to the opportunity of communing with them. 
As Paleczny (2011) writes, multiculturalism takes on different configurations, ways of the mutual ordering of components, which are both people and cultural groups (religious, ethnic-national, racial, linguistic), small and simple cultures (tribal, indigenous, native ) and great (national, civilizations), phenomena (subcultures, religious movements, aesthetic currents, philosophical currents) and processes (accommodation, amalgamation, separation, segregation, conflict, acculturation, assimilation), types of identity and ideologies and many other components. Multiculturalism as a plurality and diversity of constituent elements leads to ordering the rules of dependence (inferiority or equivalence, symmetry or asymmetry) between them. Component connection systems, a structural pattern of ordering relationships between them, can be called pluralism (Paleczny, 2011: 39).

According to Smolicz, cultural pluralism assumes that "that each ethnic group will have the opportunity to cultivate their patterns of community life as well as cultural heritage and language, without paying special attention to the issue of facilitating cultural interactions" (Smolicz, 1999: 54-55).

It turns out that in the US, immigrants are not assimilated quickly, maintaining a sense of separateness and cultivating the language and traditions of the country of ancestors for many generations. Relations between the native inhabitants of the United States and the white majority dominated by the processes of civic integration and language and religious acculturation occur more slowly in the sphere of personality and attitudes (Paleczny, 2007: 34-35).

In most large American cities, there are not only black, Chinese, Puerto Rican, and Latin (Barrios) neighborhoods, but, as in Chicago, belonging to individual European nations (Polish, Greek, Czech, Portuguese districts, etc.). This fact means that American society is not a melting pot, but a mosaic in which each group strongly emphasizes its separateness resulting from its origin.

\section{Conclusion}

By the presence of numerous minorities in the society of the United States, which retain elements of traditional cultures and ties with the countries of their ancestors, while identifying with the American people, we can speak of cultural pluralism in the US. From the point of view of the course of adaptation processes, the specific circumstances of immigration to the United States are essential. Particularly important here are closely related to each other: the nature of the arrival (which is assigned the appropriate category in US immigration statistics: refugees, immigrants, connecting with families or people coming to visit) and who was the sponsor (US government, non-governmental institutions, family, friends, acquaintances, church).

To function efficiently in a new environment, it became necessary to learn about different behavior patterns and at least superficially adapt to them (Halik \& Nowicka, 2002: 32-34). Living in the US required immigrants to be "reprogrammed" (referring to the concept of "mental programming" by Geert Hofstede) and to adapt to a different way of organizing everyday life and work. Awareness of this fact and learning how to proceed in new conditions came with time, as the years went by, and they settled in the United States. These processes were complicated, so immigrants were not able to root their habits, culture, and the world they came from, hence their cultural separateness and cultural pluralism visible in the United States.

The United States remains the most attractive target of modern migrants not because they offer social assistance like European countries, but because the much more liberal economy 
existing there gives everyone, regardless of their origin, equal opportunities to improve their position in society through economic activities, education or military service, as well as every citizen has the right to preserve their cultural separateness.

Cultural pluralism and the preservation of its separate national identity while being shared (with others, regardless of their origin) works for the benefit of the US in the economic, economic, and social field. The increase in the share of immigrants in the population of the USA is treated as a factor positively influencing the international position of the United States and its economic efficiency. Currently, every fourth modern American has strong relationships with another country or country due to the origin or origin of their parents. The United States now has the largest immigrant community in the world, hence "diversity" in American society while maintaining the unity of the country.

Cultural pluralism can also refer to fair and diverse representation in social media of various cultural and social groups, including ethnic, linguistic, national, and religious minorities. Its existence consists of presenting multiple topics and opinions in the media, socializing the recipients through various forms of participation and access to the media, the ability to choose between different kinds of interaction, and presenting all values, views, and roles with which recipients belonging to different cultural groups can identify and social. The pluralism understood in this way promotes above all diversity focused on the interaction between cultures in a given country or region, exchange of information, intercultural dialogue, mutual learning, and understanding of concepts derived from various environments defined by ethnicity, religion, and language.

\section{References}

Albański, Łukasz, and Małgorzata Krywult-Albańska (2012). Społeczno-ekonomiczny profil imigrantów w Wisconsin - analiza danych spisowych, Studia Migracyjne- Przegląd Polonijny, 38(4): 117-129.

Bastiani, Carl A. (1984). Polityka rządu Stanów Zjednoczonych wobec grup etnicznych, Lublin: Studia Polonijne.

Boehm, Deborah (2011). US-Mexico Mixed Migration in an Age of Deportation: An Inquiry into the Transnational Circulation of Violence, Refugee Survey Quarterly, 30 (1): 1-21. https://doi.org/10.1093/rsq/hdq042

Chmaj, Mark (1999). Polityka, ustrój, idee. Lublin: Sokół.

Chmaj, Mark and Joanna Marszałek-Kawa (2004). Encyklopedia wiedzy politycznej. Toruń: Sokół.

Fish, Stanley (1997). Boutique multiculturalism, or why liberale are incapable of thinking about hale speech, Critical Inquiry, 23(2): 378-395.

Gęsiak, Leszek (2007) Wielokulturowość. Rola religii w dynamice zjawiska. Kraków: wyd. WAM.

Golka, Marian (2010) Imiona wielokulturowości. Warszawa: Warszawskie Wydawnictwo literackie MUZA SA.

Gupta, Amit (2016). Demographic Changes and U.S. Foreign Policy, 60(3): 353-365. https:// doi.org/10.1016/j.orbis.2016.05.004

Halik, Teresa, and Eva Nowicka (2002). Wietnamczycy w Polsce. Integracja czy izolacja? Warszawa: Instytut Orientalistyczny, Wydział Neofilologii UW.

Jones, Maldwyn Allen (1969). American Immigration. Chicago: The University of Chicago 
Press.

Kymlicka, Will (1999). Liberal Complacencies. In: J. Cohen, M. Howard, M.C. Nussbaum (eds.), Is Multiculturalism Bad for Women? Princeton: Princeton University Press: 31-34.

Mather, Mark (2012), What's Driving the Decline in U.S. Population Growth?, Population Reference Bureau, Washington, D.C. https://www.prb.org/us-population-growthdecline/

Paleczny, Tadeusz (2002). Meandry wielokulturowości: oblicza pluralizmu w społeczeństwach wielokulturowych — USA i Brazylia, Państwo i Społeczeństwo, No. 2: 265-278.

Paleczny, Tadeusz (2007). Zjawisko uniwersalizacji kulturowej jako wymiar procesu globalizacji, Krakowskie Studia Międzynarodowe, No. 2: 167- 185.

Paleczny, Tadeusz (2010). Uniwersalizacja kulturowa w procesach globalizacji, In B. Bodzioch Bryła, R. Szczepaniak, K. Wałczyk (red.), Globalizacja w kulturze, upowszechnienie czy uproszczenie. Kraków: Wyższa Szkoła Filozoficzno-Pedagogiczna „Ignatianum”, Wydawnictwo WAM: 17- 36.

Passel, Jeofrey S., D’Vera Cohn, and Ana Gonzalez-Barrera (2013). Population Decline of Unauthorized Immigrants Stalls, May Have Reversed. Washington D.C.: Pew Research Center.

Piwowarski, Władysław (1980). Pluralizm społeczno- kulturowy a religia, Rocznik Nauk Społecznych, Nr. 8: 105-123.

Smolicz, Jerzy (1999). Wspólkultury Australii. Warszawa: Oficyna Naukowa.

Szczepański, Marek, and Anna Śliz (2011). Wielokulturowe miasta, Przegląd socjologiczny, 60 (2-3): 47- 66.

Wilczyński, Witold J. (2017). Imigracja a pozycja międzynarodowa USA w perspektywie europejskiej, Przegląd Geopolityczny, 19: 84-103.

U.S. Customs and Border Protection. 2014. U.S. Border Patrol Fiscal Year Staffing Statistics (FY 1992 - FY 2014). Washington, DC: U.S. Customs and Border Protection. http:// www.cbp.gov/sites/default/files/documents/BP\%20Staffing\%20FY1992pFY2014_0. pdf 